\title{
Financial development, trade openness and economic growth in Pakistan: A granger causality approach
}

\author{
Abbas Ali Chandio ${ }^{1}$, Abdul Rehman ${ }^{2}$, Yuansheng Jiang ${ }^{1, *}$, Mumtaz Ali Joyo ${ }^{3}$ \\ ${ }^{1}$ College of Economics and Management, Sichuan Agricultural University, Chengdu, China \\ ${ }^{2}$ College of Economics and Management, Anhui Agricultural University, Hefei, China \\ ${ }^{3}$ Department of Agricultural Economics, Sindh Agriculture University, Tandojam, Pakistan
}

\section{A R T I C LE IN F O}

\section{Article history:}

Received 7 August 2016

Received in revised form

19 March 2017

Accepted 19 March 2017

\section{Keywords:}

Economic growth

Financial development

Trade openness

Granger causality

\begin{abstract}
A B S T R A C T
This study aims to examine the direction of causality between financial development, trade openness and economic growth in Pakistan over the period 1970 to 2014. For this undertaking, statistical tools such as ADF and P-P unit root tests have been used to check stationery of the series and Cointegration test has been used to determine the long run relationship between the study variables. The causality relationship among variable is examined by Granger causality approach. The result of ADF test revealed that all variables become stationery at first difference which confirm to co integration test. Furthermore, the results of Johansen Co integration test indicate that there is existence of a long run relationship between the variables. On the other hand, the results of Granger causality test show that there is a causality relationship which is bi-directional running from economic growth to financial development. While, the results show that there is also causality relationship which is bi-directional running from trade openness to financial development. Our study results revealed that unidirectional causality relationship found out between trade openness to economic growth. The results suggest that financial development and trade openness plays an important role in boosting economic growth in Pakistan.

(C) 2017 The Authors. Published by IASE. This is an open access article under the CC BY-NC-ND license (http://creativecommons.org/licenses/by-nc-nd/4.0/).
\end{abstract}

\section{Introduction}

It has been controversial about financial development importance and its role in intermediation of finance that plays significantly in growth of economy for the past few decades and it has occupied an important position in the financial development. It has also been suggested by many researchers, for instance, Gurley and Shaw (1967) and Goldsmith (1959) that financial development would be an important milestone that can foster the economic growth by improving different sectors, for instance, savings, improving allocation of loanable funds, and it also improving the capital accumulation (Beck, 2003; Kashyap and Stein, 2000; McKinnon, 1973). Furthermore, they argued that it is necessary for well-developed financial markets in developing countries. On the other hand, FitzGerald (2006) stated that development of finance and growth of economy has set up the attentions of economic

\footnotetext{
* Corresponding Author.

Email Address: yjiang@sicau.edu.cn (Y. Jiang)

https://doi.org/10.21833/ijaas.2017.04.012

2313-626X/C 2017 The Authors. Published by IASE.

This is an open access article under the CC BY-NC-ND license

(http://creativecommons.org/licenses/by-nc-nd/4.0/)
}

experts over the time, however, means and trend of connectedness have continued unsolved altogether with model and empirics.

There are many factors that accelerate the economies of developing countries other than savings and credit. Therefore, application of appropriate means of resources relies mainly on the economic development and progress of the country in production process and equal income distribution among the individuals in that particular society. Simon (1971) stated that actual nation-wide income, country's total population and income per capita are considered important in economic growth which is formulated in a long-term process. Furthermore, Todaro and Smith (2003) reported that economic growth is a phenomenon that is continuously affected by the productivity of the country which has been improved over an extended phase of period.

Unpredictability in growing rates among diverse states has been discussed by many researchers. Capital and labour are the important factors that cause divergences between development due to variations in prospects (Piazolo, 1995).Similarly, there are many factors responsible in Pakistan which cause poor growth such as rate of inflation, reduction in exports, fluctuations in foreign loans 
and services, poor management of social wealth, administrative scenarios and unrest and wicked stability conditions which are prevailing in the country (Iqbal and Zahid, 1998). Meanwhile, Dwyfor Evans et al. (2002) assessed the 82 economies and discussed relative shares of human resources and financial growth. Their study simulated that growth is dependent on money distribution and also emphasized on the complementarities of financial and capital growth. Similarly, role of commercial liberalization in macroeconomic performances in Pakistan was reported by Chaudhry et al. (2012). Their study used the broad money ratio, capitalization of market, credit allocated to private sector, trade openness in markets and FDI taken as development of financial sector and Gross Domestic Product and investing for the financial presentations. His findings revealed that economic growth is being affected by development of financial sector which has constructive short run as well as extensive impact on it.

Trade openness and economic performances are linked together by many theoretical and empirical studies as well as connections exist among financial development and growth financial market. Positive relationship between economic growth and openness is being supported by many researchers such as Balassa (1985), Sala-i-Martin and Roubini (1991) and Frankel and Romer (1996) while on the contrary, an encouraging trend between growth and financial development is also presented by others (Diaz-Alejandro, 1985; Jayaratne and Strahan, 1996; King and Levine, 1993; Levine and Zervos, 1996).

Relationship between economic and financial development was examined by Abu-Bader and AbuQarn (2005) in Egypt. They statistically analysed the data from annual time series data of 40 years and used VAR methodologies on 4 different variables viz., ratio between bank credit and private sector to nominal GDP, GDP to measure economic growth, ratios of credit distributed to private firms that were non-financial and credit allocated to domestic use and representation of proxies for the development of finance. Their findings illustrate that increase in private investment was accelerated due to financial liberalization in 1990 that led to rebound of economic performances in Egypt. Impact of financial development and openness to international trade was investigated by Wong (2005) on the economic growth in Malaysia. Similarly, a model was represented which is known as error correction model that indicated that openness to the international trade has been affected significantly due to its impact on economic growth.

\section{Existing review of literature}

Economic growth has been remained a debated and mixed subject due to many factors. To cope with this kind of literature, a theoretical study needs to explore the kind of the relationship both in economic growth and investment sector that suggests that it could be positive or negatively affect the actual financial performances by marking the conformation of reserves (Bencivenga and Smith, 1991) delivering information (Greenwood and Jovanovic, 1990) and it affects the extent of credit rationing (Boyd and Smith, 1997).

Influence of bank credit and stock market fluidity on gross domestic product development was examined by (Dey and Flaherty, 2005) by means of a two-stage regression model. They found that stock market liquidity and bank credit are not reliable elements of gross domestic product growth. Turnover is not an important element of GDP development while bank development is a strong determinant. In contrast to the recent findings for the US, Cappiello et al. (2010) studied and found that supply of credit affects real economy significantly, both in relation to volumes and credit standards which is pragmatic on enterprises of loans. In other words, GDP is affected positively and statistically significantly by change in loan growth.

Empirical investigations have been conducted extensively aimed to test the theoretical developments while using different techniques. A strong evidence connection between the economic growth and exogenous constituent of financial development was received by the results provided from these studies. It is less or more stable with the conventional view on the association ship between financial growth and economic development. Relationship between real activity and financial markets were first studied by Gurley and Shaw (1967) but much of literature was insufficient on the relationship between real output and financial markets until the 1970s when it was further supported by Goldsmith (1959), McKinnon (1973) and FAO (1973) who discovered that there was significant correlation exists between expansion of economic markets and level of per capita income.

Later on, it was re-examined by Yanikkaya (2003) who studied an issue that was segregated influence of trade directness on industrialised as well as on developing economies. In contrast to the accepted believes, their experiential work discovered the negative correlation between growth and trade openness in developing countries while there was constructive correlation between growth and trade directness in case of established countries.

Overseas direct investment on the growth driving element for the budget was mentioned by many studies such as Ghosh and Van den Berg (2006) and Iqbal et al. (2010). An important issue that most of developing economies suffer is gap in savinginvestment and overseas direct investment limits this cavity by improving the output, recent expertise, producing opportunities for youth while also enhancing the competition (Kobrin, 2005). There was an increase in GDP from 0.64 percent to 3.9 percent from the period of 2004 to 2007 in foreign direct investment in Pakistan which was more than any year throughout the time period of 30 years from 1980 to 2011. After that, it was declined constantly and its value was recorded as 0.62 percent of GDP. Security conditions were thought to 
be insecure and unpredictable since the start of 2008. This kind of situations created many unfavourable conditions and created capital flight, reduction in the overseas direct investment, enhanced the increase in prices, and currency depreciation. Many preceding studies have stressed on the occurrence of non-linear association of increasing prices with extending of growth and visualized the low prices could promote progress, as well as within this, enhanced prices have potent relationship with the growth (Ghosh and Phillips, 1998; Hussain, 2005; Khan and Ssnhadji, 2001; Mubarik, 2005; Sarel, 1996). Exchange rate is stimulator of growth as outpouring in exchange rates which enhances the exports and therefore, it is useful for goods demand (Mahmood et al., 2011).

There are many previous studies that illustrate the trade openness which is growth enhancer. This association between financial growth and trade openness is also studied by many economists and some of the researchers have examined that trade openness is growth promoter (Anorou and Ahmad, 2000; Kahnamoui, 2013; Marelli and Signorelli, 2011) while Findlay (1984) said that it has no impact on growth promotion.

Many studies have revealed that there is positive effect on economic growth due to exports (Ullah et al., 2009). Although, it has been extensively investigated that exports lead growth empirically but direction of causality is debatable. Some manufacturing companies in developing countries may suffer substantial metamorphosis as an outcome of acquiring, experiences, literal modernization and division of technology through FDI. In such conditions, even if there is no existence of government policy that effort to attain expansion by promoting and inspiring trade policies with any charges, it is also likely to increase growth productivity. Manufacturers can export their surplus if local petition is not increased as much as the growth productivity in these booming industries.

Hence, economic growth can be promoted through development of export in a country. However, if industrial production is less than domestic demand progress, it may be indication of reduction in exports. For example, enhancement in domestic productivity is induced by the domestic demand which is resulted in decreased export, depreciation in performance can affect the export of the country (Lee and Huang, 2002). Many studies are available concerning the association between financial and economic development. There is consent in many studies that economic growth is assisted by financial development through different channels comprising increase in export (Shahbaz and Mafizur Rahman, 2014). According to Hur et al. (2006), there could be an optimistic influence on export in addition to effect due to proper growth in the country (Shahbaz, 2009).Therefore, it is very significant reason to have a well-structured and developed system in global trade.

Relationship between trade and financial development from the scale perspective was investigated by Beck (2003) and (Svaleryd and Vlachos, 2005).They found that financial sector had affected the trade. A well-developed economic sector means extra positive to the private sector and it facilitates businesses with the exploitation of exterior funding so that industries can overwhelmed restrictions of liquidity. A study was conducted to evaluate the relationship of economic growth and financial development in China and consequences revealed that maximum of the indicators of financial development have encouraging correlation with economic growth (Zhang et al., 2012).Furthermore, Al-Yousif (2002) found bi-directional connectedness between GDP growth and financial progress for the period of thirty years from 1970 to 1999 for developing countries. Similarly, Lartey (2010) studied the impact of financial development on economic growth for a penal of 74 and they found that there is positive effect on economic growth induced by financial development which does not change with the level of financial development.

Much of work has been done by many investigators on the effects of export on financial development and its positive influence on economic development (Jordaan and Eita, 2007; Ullah et al., 2009). Nevertheless, Pazim et al. (2009) investigated rationality of export-led growth theory for Malaysia, Philippines and Indonesia by utilizing panel data investigation and found that there was no significant relationship between output growth and export. Similarly, it was investigated that the export-led growth theory for Pakistan and validated this hypothesis (Shahbaz et al., 2011).

In contrast to other researchers, (Vamvakidis, 2002) reported that economic growth is positively affected by openness to global trade and it leads to enhance the concentration that would increase the output by utilizing further scale economies. Moreover, it could be expecting that more openness means more competitiveness and further it will stimulate the productivity and $\mathrm{d}$ which in response catalyses economic growth. Relationships for causality among trade openness, financial development and economic growth (GDP) for the Turkish economy were examined by Yucel (2009) for the period between 1989 to 2007. Econometric method used for this test was Johansen cointegration and Granger causality to check the test amongst the variables. Results from these studies resulted that trade openness has positively affected while commercial growth has a negative influence on growth.

Further, pivotal association ship between trade openness, financial development and economic growth in Japan was empirically investigated by Soukhakian (2007) for the period of 1960 to 2003. Findings suggested that existence of long run stability correlation between trade, financial development and economic growth in Japan among domestic credit, growth and trade. Similarly, Granger Causality results suggest that financial development gives causation to economic growth that is supported by growth-driven trade (GDT) hypothesis 
which privileges that economic development results "more well-organized imports and exports" for Japan. Therefore, the main aim of this research is to determine the direction of causality between financial development, trade openness and economic growth in Pakistan over the period 1970-2014.

\section{Methodology}

\subsection{Data source}

In this paper time series data has been used over the period 1970 to 2014 containing variables, Gross Domestic Product (GDP) in constant 2005 US\$, domestic credit provided by the banking sector (DC) as a ratio of GDP and is measured for financial development and trade openness (TO) which is the ratio of total trade (Exports + Imports) to GDP,) Siddiki (2002) and Yucel (2009).

\subsection{Empirical econometric analysis}

This empirical study determines the causality relationship among financial development, trade openness and economic growth in Pakistan. The ADF (Dickey and Fuller, 1981) and P-P (Phillips and Perron, 1988) unit root tests have been applied whether data series are stationary.

In order to investigate the co-integration association between dependent variable and independent variables. Johansen and Juselius (1990) co-integration test is applied. For direction of causality relationship between DC, TO and GDP Granger-causality test have been employed.

The Functional form is (Eq. 1):

$G D P=f(D C, T O)$

The function can also be presented in log-linear stipulations of the variables have been used and the following equation is estimated (Eq. 2):

$\operatorname{LnGDP}_{t}=\beta_{0}+\beta_{1} \operatorname{lnDC}_{t}+\beta_{2} \operatorname{lnTO}_{t}+\varepsilon_{t}$

Where $G D P_{t}, \quad D C_{t}$ andTO $O_{t}$ represent economic growth, domestic credit provided by the banking sector and trade openness respectively. $\beta_{1}$ and $\beta_{2}$ give the coefficient of the independent variables.

\subsection{ADF unit root test}

In this study, ADF unit root test and P-P unit root test has been applied to check whether series are stationary. In our empirical study, null hypothesis for both tests includes ADF and P-P is that variables has unit root. If the variables are non-stationary at their level, we again checked stationary of the variables after taking first differences. I (0) represent stationary of the series at their level and I (1) denoted stationary of the series at their first differences. Enders (1995) suggests that testing for stationary of the series should be started from trend and intercept. The model specified as follows (Eq. 3):
$\Delta y_{t-1}=\alpha_{0}+\lambda y_{t-1}+\alpha_{2} t+\sum_{i=2}^{p} \beta_{j} \Delta y_{t-1+1}+\varepsilon_{t}$

where,

$y$ denotes dependent variable

$t$ denotes for trend

$a$ represent for intercept

$\varepsilon_{t}$ stand for error term

$P$ denotes for lag level

\subsection{Johansen Co-integration test}

If DC, GDP and TO have the same order of integration, then we can apply Johansen cointegration test to determine the long run relationship among the variables. Johansen cointegration technique is used to test the cointegration.

The methodology of Johansen co-integration is specified as follows (Eq. 4);

$X_{t}=\Pi_{1} X_{t-1}+\ldots+\Pi_{k} X_{t-k}+\mu+\varepsilon_{t}$

where,

$X_{t}, X_{t-1}$ and $X_{t-k}=$ represent vectors of level and lagged values of the variables which are integrated of order I (1)

$\Pi_{1}$ and $\Pi_{\mathrm{k}}=$ represent for coefficient of matrices $\mu=$ stand for intercept vector

$\varepsilon_{\mathrm{t}}=$ stand for vector of random errors

\subsection{Pair wise granger causality test}

In this study, pair wise Granger causality approach has been used to find the directions of relationship between domestic credit, trade openness and economic growth in Pakistan. The association ship among granger causality and cointegration is discussed by Granger (1988).

Granger methodology can be specified as follows (Eqs. 5 and 6)

$Z_{t}=\sum_{j=1}^{m} a_{j} Z_{t-j}+\sum_{j=1}^{m} b_{j} Y_{t-j}+\varepsilon_{t}$

$Y_{t}=\sum_{j=1}^{m} c_{j} Z_{t-j}+\sum_{j=1}^{m} d_{j} Y_{t-j}+\mu_{t}$

If $b_{j}$ is significant; $Y_{j}$ Granger-cause $Z_{j}$. Whereas, if $c_{j}$ is different from zero; $Z_{t}$ Granger-cause $Y_{t}$.

\section{Results and discussions}

\subsection{Results of ADF unit root test}

Stationary of the data has been investigated by ADF and P-P unit root tests. The estimated results of the ADF test and P-P test are reported in (Tables 1 and 2) reveal that DC and GDP are non-stationary at their level 1(0), while TO attained stationary at 5\% of significance their level. However, for same order of integration we again checked DC, TO and GDP became stationary at their first difference. This implies that all variables are integrated at I (1), as showing less than 0.05 by their probability values. The computed ADF statistics test and Adj. t-Stat test 
significance.

Table 1: ADF unit root test

\begin{tabular}{|c|c|c|c|c|}
\hline \multirow{2}{*}{ Variables } & \multicolumn{2}{|c|}{ At level } & \multicolumn{2}{|c|}{ First Difference } \\
\hline & ADF Statistic & Critical values & ADF Statistic & Critical values \\
\hline LnTO & $\begin{array}{c}-3.453922^{* *} \\
(0.0573)\end{array}$ & $\begin{array}{c}1 \%-4.180911 \\
5 \%-3.515523 \\
10 \%-3.188259\end{array}$ & $\begin{array}{c}-7.736041^{*} \\
(0.0000)\end{array}$ & $\begin{array}{c}1 \%-3.592462 \\
5 \%-2.931404 \\
10 \%-2.603944\end{array}$ \\
\hline $\operatorname{LnDC}$ & $\begin{array}{c}-2.399663 \\
(0.3747)\end{array}$ & $\begin{array}{c}1 \%-4.180911 \\
5 \%-3.515523 \\
10 \%-3.188259\end{array}$ & $\begin{array}{c}-5.075781^{*} \\
(0.0009)\end{array}$ & $\begin{array}{c}1 \%-4.186481 \\
5 \%-3.518090 \\
10 \%-3.189732\end{array}$ \\
\hline LnGDP & $\begin{array}{c}-2.277589 \\
(0.4368)\end{array}$ & $\begin{array}{c}1 \%-4.180911 \\
5 \%-3.515523 \\
10 \%-3.188259\end{array}$ & $\begin{array}{c}-5.494114^{*} \\
(0.0003)\end{array}$ & $\begin{array}{c}1 \%-4.186481 \\
5 \%-3.518090 \\
10 \%-3.189732\end{array}$ \\
\hline
\end{tabular}

Table 2: P-P unit root test

\begin{tabular}{|c|c|c|c|c|}
\hline \multirow{2}{*}{ Variables } & \multicolumn{2}{|c|}{ At level } & \multicolumn{2}{|c|}{ First Difference } \\
\hline & Adj.t-Stat & Critical values & Adj. t-Stat & Critical values \\
\hline LnTO & $\begin{array}{c}-3.296291^{* * *} \\
(0.0802)\end{array}$ & $\begin{array}{c}1 \%-4.180911 \\
5 \%-3.515523 \\
10 \%-3.188259\end{array}$ & $\begin{array}{c}-8.338829 * \\
(0.0000)\end{array}$ & $\begin{array}{c}1 \%-4.186481 \\
5 \%-3.518090 \\
10 \%-3.189732\end{array}$ \\
\hline LnDC & $\begin{array}{c}-2.467689 \\
(0.3418)\end{array}$ & $\begin{array}{c}1 \%-4.180911 \\
5 \%-3.515523 \\
10 \%-3.188259\end{array}$ & $\begin{array}{c}-4.999729 * \\
(0.0011)\end{array}$ & $\begin{array}{c}1 \%-4.186481 \\
5 \%-3.518090 \\
10 \%-3.189732\end{array}$ \\
\hline LnGDP & $\begin{array}{c}-2.470614 \\
(0.3404)\end{array}$ & $\begin{array}{c}1 \%-4.180911 \\
5 \%-3.515523 \\
10 \%-3.188259\end{array}$ & $\begin{array}{c}-5.405321 * \\
(0.0003)\end{array}$ & $\begin{array}{c}1 \%-4.186481 \\
5 \%-3.518090 \\
10 \%-3.189732\end{array}$ \\
\hline
\end{tabular}

\subsection{Results of Johansen Co-integration test}

In order to find out the long run relationship between variables the Johansen Co-integration test has been used. The estimated results of Johansen cointegration analysis reported in Tables 3 and 4 . The values of Trace statistic (57.39378) and the values of Max-Eigen statistic (48.01479) which are greater than their critical values (29.79707), (21.13162), which are indicating that there exists a long run relationship among dependent and independent variables. This rejects the null hypothesis of there is no co-integration. In both, the Trace statistic and Max-Eigen statistic tests shows one co-integration equation at the $5 \%$ level. Trace Statistic test indicates 1 co-integration equation at the 0.05 level. Max-Eigen Statistic test indicates 1 co-integration equation at the 0.05 level.

Table 3: Unrestricted Co-integration rank test (Trace Statistic)

\begin{tabular}{ccccc}
\hline Eigenvalue & Trace Statistic & Critical Value 0.05\% & Prob.** & Hypothesized No. of CE(s) \\
\hline 0.672616 & 57.39378 & 29.79707 & 0.0000 & None ${ }^{*}$ \\
0.191038 & 9.378996 & 15.49471 & 0.3315 & At most 1 \\
0.006094 & 0.262865 & 3.841466 & 0.6082 & At most 2 \\
\hline
\end{tabular}

Table 4: Unrestricted Co-integration rank test (Max-Eigen Statistic)

\begin{tabular}{ccccc}
\hline Eigenvalue & Max-EigenStatistic & Critical Value 0.05\% & Prob.* & Hypothesized No. of CE(s) \\
\hline 0.672616 & 48.01479 & 21.13162 & 0.0000 & None ${ }^{*}$ \\
0.191038 & 9.116131 & 14.26460 & 0.2766 & At most 1 \\
0.006094 & 0.262865 & 3.841466 & 0.6082 & At most 2 \\
\hline
\end{tabular}

\subsection{Pairwise granger causality test}

Following Johansen co-integration investigation, now we have to determine the direction of the long run relationship between DC, TO and GDP by using Granger Causality approach. Table 5 indicates the estimated results of Granger Causality test.

Table 5 revealed that the null hypothesis of the model is that GDP does not Granger-cause DC is rejected, which is evidence of bi-directional causality runs from economic growth to Domestic credit. Further, results indicates that the null hypothesis of the model is that TO does not Granger-cause DC is rejected, which reveal that bi-directional causality runs from trade openness to Domestic credit. Whereas, the null hypothesis of the model is that TO does not Granger-cause GDP is rejected, this shows that uni-directional causality runs from trade openness to economic growth.

Our finding on causal relationship from economic growth to domestic credit and trade openness to economic growth conforms to other studies by (Adamopoulos, 2010; Alkhuzaim, 2014; Gokmenoglu et al., 2015; Korkmaz, 2015; Marshal et al., 2015; Mishra et al., 2009; Nwakanma et al., 2014; Vazakidis and Adamopoulos, 2009).

\section{Conclusion}

This study empirical examines the long run relationship and the direction of causality between domestic credit, trade openness and economic 
growth in Pakistan over the period 1970-2014.To this aim, we first started with stationary of unit root tests of the series in question applying ADF and P-P unit root tests. The results showed that DC and GDP are non-stationary at level $1(0)$, while T0 attained stationary at $5 \%$ of significance their level. However, for same order of integration we again checked DC, TO and GDP became stationary at their first difference forms.After that Johansen co-integration test have been used and found that there is existence of long run association ship between DC, TO and GDP in Pakistan. In further step we have been used Granger Causality approach which shows that there is a causality relationship which is bi-directional running from economic growth to domestic credit. On the other hand, the results indicates that there is also causality relationship which is bi-directional running from trade openness to domestic credit and unidirectional causality relationship found out between trade openness to economic growth.

Table 5: Pairwise granger causality test

\begin{tabular}{cccc}
\hline Null Hypothesis & Obs. & F-Statistic & Prob. \\
\hline LnGDP does not Granger Cause LnDC & \multirow{2}{*}{41} & 3.03929 & 0.0313 \\
LnDC does not Granger Cause LnGDP & & 4.41513 & 0.0059 \\
LnTO does not Granger Cause LnDC & \multirow{2}{*}{41} & 3.07579 & 0.0299 \\
LnDC does not Granger Cause LnTO & & 3.61799 & 0.0153 \\
LnTO does not Granger Cause LnGDP & \multirow{2}{*}{41} & 5.57308 & 0.0016 \\
LnGDP does not Granger Cause LnTO & & 0.14591 & 0.9635 \\
\hline
\end{tabular}

\subsection{Policy implications}

Above empirical findings of this study clearly indicate that there is positive relationship among economic growth and domestic credit, as well as positive relationship exists among trade openness and economic growth. Therefore, study recommended that government should try to reforming financial system. Hence, Pakistan should promote its trade linearization policy, in order to boost the financial development and economic growth.

\section{References}

Abu-Bader S and Abu-Qarn A (2005). Financial development and economic growth: Time series evidence from Egypt. Journal of Policy Modeling, 30(5): 887-898.

Adamopoulos A (2010). The relationship between credit market development and economic growth. American Journal of Applied Sciences, 7(4): 518-526.

Alkhuzaim W (2014). Degree of financial development and economic growth in Qatar: Cointegration and causality analysis. International Journal of Economics and Finance, 6(6): 57-69.

Al-Yousif YK (2002). Financial development and economic growth: Another look at the evidence from developing countries. Review of Financial Economics, 11(2): 131-150.

Anorou E and Ahmad Y (2000). Openness and Economic Growth: Evidence from selected ASEAN countries. Indian Economic Journal, 47(3): 110-117.

Balassa B (1985). Exports, policy choices, and economic growth in developing countries after the 1973 oil shock. Journal of Development Economics, 18(1): 23-35.

Beck T (2003). Financial dependence and international trade. Review of International Economics, 11(2): 296-316.

Bencivenga VR and Smith BD (1991). Financial intermediation and endogenous growth. The Review of Economic Studies, 58(2): 195-209.

Boyd JH and Smith BD (1997). Capital market imperfections, international credit markets, and nonconvergence. Journal of Economic Theory, 73(2): 335-364.

Cappiello L, Kadareja A, Kok Sorensen C, and Protopapa M (2010). Do bank loans and credit standards have an effect on output? A panel approach for the euro area. ECB Working Paper No.
1150, Available online at: SSRN: https://ssrn.com/ abstract $=1535995$

Chaudhry IS, Malik A, and Farooq F (2012). Financial Liberalization and Macroeconomic Performance: Empirical Evidence from Pakistan. British Journal of Economics, Finance and Management Sciences, 4(1): 18-29.

Dey MK and Flaherty S (2005). Stock exchange liquidity, bank credit, and economic growth. In the Max Fry Conference on Finance and Development, University of Birmingham, The Business School University House, Birmingham, UK: 1-42.

Diaz-Alejandro C (1985). Good-bye financial repression, hello financial crash. Journal of Development Economics, 19(1-2): $1-24$.

Dickey DA and Fuller WA (1981). Likelihood ratio statistics for autoregressive time series with a unit root. Econometrica: Journal of the Econometric Society, 49(4): 1057-1072.

Dwyfor Evans A, Green CJ, and Murinde V (2002). Human capital and financial development in economic growth: New evidence using the translog production function. International Journal of Finance \& Economics, 7(2): 123-140.

Enders W (1995). Applied econometric time series (Wiley series in probability and mathematical statistics). John Wiley \& Sons, New Jersey, USA.

FAO (1973). Financial deepening in economic development. Food and Agriculture Organization, Rome, Italy.

Findlay R (1984). Growth and development in trade models. Handbook of International Economics, 1: 185-236.

FitzGerald V (2006). Financial development and economic growth: A critical view. Background Paper for World Economic and Social Survey, Oxford University, Oxford, UK.

Frankel JA and Romer D (1996). Trade and growth: An empirical investigation. National Bureau of Economic Research, w5476, University of Cambridge, Cambridge, UK.

Ghosh MAR and Phillips MS (1998). Inflation, disinflation, and growth. International Monetary Fund, Washington, USA.

Ghosh RA and Van den Berg HF (2006). Foreign direct investment and economic growth: A time-series approach. Global Economy Journal, 6(1): 1-21.

Gokmenoglu KK, Amin MY, and Taspinar N (2015). The relationship among international trade, financial development and economic growth: The case of Pakistan. Procedia Economics and Finance, 25: 489-496.

Goldsmith RW (1959). Financial structure and development as a subject for international comparative study. In: Goldsmith RW (Ed.), The comparative study of economic growth and 
structure: 114-123. National Bureau of Economic Research, New York, USA.

Granger CW (1988). Causality, cointegration, and control. Journal of Economic Dynamics and Control, 12(2-3): 551-559.

Greenwood J and Jovanovic B (1990). Financial development, growth, and the distribution of income. Journal of Political Economy, 98(5): 1076-1107.

Gurley J and Shaw E (1967). Financial structure and economic development. Economic Development and Cultural Change, 15(3): 257-268.

Hur J, Raj M, and Riyanto YE (2006). Finance and trade: A crosscountry empirical analysis on the impact of financial development and asset tangibility on international trade. World Development, 34(10): 1728-1741.

Hussain M ( 2005). Inflation and growth: Estimation of threshold point for Pakistan. International Journal of Economics and Finance, 3(5): 262-276.

Iqbal MS, Shaikh FM, and Shar AH (2010). Causality relationship between foreign direct investment, trade and economic growth in Pakistan. Asian Social Science, 6(9): 82-89.

Iqbal Z and Zahid GM (1998). Macroeconomic determinants of economic growth in Pakistan. The Pakistan Development Review, 37(2):125-148.

Jayaratne J and Strahan PE (1996). The finance-growth nexus: Evidence from bank branch deregulation. The Quarterly Journal of Economics, 111(3): 639-670.

Johansen S and Juselius K (1990). Maximum likelihood estimation and inference on cointegration-with applications to the demand for money. Oxford Bulletin of Economics and Statistics, 52(2): 169-210.

Jordaan AC and Eita JH (2007). Export and economic growth in Namibia: A granger causality analysis. South African Journal of Economics, 75(3): 540-547.

Kahnamoui F (2013). Do trade restrictions or openness affect economic growth differently in the presence of export credits?. Business and Economics Journal, 2013: 1-11.

Kashyap AK and Stein JC (2000). What do a million observations on banks say about the transmission of monetary policy? American Economic Review, 90(3): 407-428.

Khan MS and Ssnhadji AS (2001). Threshold effects in the relationship between inflation and growth. IMF Staff Papers, 48(1): 1-21.

King RG and Levine R (1993). Finance and growth: Schumpeter might be right. The Quarterly Journal of Economics, 108(3): 717-737.

Kobrin SJ (2005). The determinants of liberalization of FDI policy in developing countries: A cross-sectional analysis, 19922001. Transnational Corporations, 14(1): 67-104.

Korkmaz S (2015). Impact of bank credits on economic growth and inflation. Journal of Applied Finance and Banking, 5(1): 57-69.

Lartey EK (2010). A note on the effect of financial development on economic growth. Applied Economics Letters, 17(7): 685-687.

Lee $\mathrm{CH}$ and Huang BN (2002). The relationship between exports and economic growth in East Asian countries: A multivariate threshold autoregressive approach. Journal of Economic Development, 27(2): 45-68.

Levine R and Zervos S (1996). Stock market development and long-run growth. The World Bank Economic Review, 10(2): 323-339.

Mahmood I, Ehsanullah M and Ahmed H (2011). Exchange rate volatility \& macroeconomic variables in Pakistan. Business Management Dynamics, 1(2): 11-22.
Marelli E and Signorelli M (2011). China and India: Openness, trade and effects on economic growth. The European Journal of Comparative Economics, 8(1):129-154.

Marshal I, Onyinye NP, and Princewill WI (2015). Causality modeling of the banking sector credits and economic growth in Nigeria. International Journal of Finance and Banking Research, 1(7): 1-12.

McKinnon RI (1973). Money and capital in economic development. Brookings Institution Press, Washington, USA.

Mishra P, Das K, and Pradhan B (2009). Credit market development and economic growth in India. Middle Eastern Finance and Economics, 5(3): 92-106.

Mubarik YA (2005). Inflation and growth: An estimate of the threshold level of inflation in Pakistan. SBP-Research Bulletin, 1(1): 35-44

Nwakanma PC, Nnamdi IS, and Omojefe GO (2014). Bank credits to the private sector: Potency and relevance in Nigeria's economic growth process. Accounting and Finance Research, 3(2): 23-35.

Pazim KH, Hanim K, and Fadzim P (2009). Panel data analysis of "Export-led" Growth Hypothesis in BIMP-EAGA Countries. Avalible online at: http://mpra.ub.uni-muenchen.de/13264/.

Phillips PC and Perron P (1988). Testing for a unit root in time series regression. Biometrika, 75(2): 335-346.

Piazolo M (1995). Determinants of south korean economic growth, 1955-1990. International Economic Journal, 9(4):109-133.

Sala-i-Martin X and Roubini N (1991). Financial development, the trade regime, and economic growth. NBER Working Paper 3876. Yale University, New Haven, USA.

Sarel M (1996). Nonlinear effects of inflation on economic growth. Staff Papers, 43(1): 199-215.

Shahbaz M (2009). A reassessment of finance-growth nexus for Pakistan: Under the investigation of FMOLS and DOLS techniques. IUP Journal of Applied Economics, 8(1): 65-80.

Shahbaz M and Mafizur Rahman M (2014). Exports, financial development and economic growth in Pakistan. International Journal of Development Issues, 13(2): 155-170.

Shahbaz M, Azim P, and Ahmad K (2011). Exports-led growth hypothesis in Pakistan: further evidence. Asian Economic and Financial Review, 1(3): 182-197.

Siddiki JU (2002). Trade and financial liberalisation and endogenous growth in Bangladesh. International Economic Journal, 16(3): 23-37.

Simon K (1971). Economic growth of nations: Total output and production structure. Harvard University Press, Massachusetts, USA.

Soukhakian B (2007). Financial development, trade openness and economic growth in Japan: Evidence from Granger causality tests. International Journal of Economic Perspectives, 1(3): 118-127.

Svaleryd H and Vlachos J (2005). Financial markets, the pattern of industrial specialization and comparative advantage: Evidence from OECD countries. European Economic Review, 49(1): 113-144.

Todaro MP and Smith SC (2003). Economic Development. $8^{\text {th }}$ Edition, Pearson Education (Singapore) Pte Ltd, Delhi, India.

Ullah S, Zaman B, Farooq M, and Javid A (2009). Cointegration and causality between exports and economic growth in Pakistan. European Journal of Social Sciences, 10(2): 264-272.

Vamvakidis A (2002). How robust is the growth-openness connection? Historical evidence. Journal of Economic Growth, 7(1): 57-80. 
Vazakidis A and Adamopoulos A (2009). Credit market development and economic growth. American Journal of Economics and Business Administration, 1(1): 34-40.

Wong HT (2005). Openness, financial development and economic growth in Malaysia. International Journal of Business and Society, 6(1): 93-121.

Yanikkaya H (2003). Trade openness and economic growth: A cross-country empirical investigation. Journal of Development Economics, 72(1): 57-89.
Yucel F (2009). Causal relationships between financial development, trade openness and economic growth: The case of Turkey. Journal of Social sciences, 5(1): 33-42.

Zhang J, Wang L, and Wang S (2012). Financial development and economic growth: Recent evidence from China. Journal of Comparative Economics, 40(3): 393-412. 